Home Bound 
This page intentionally left blank 


\section{Home Bound}

Filipino American Lives

across Cultures, Communities, and Countries

\section{Yen Le Espiritu}


University of California Press

Berkeley and Los Angeles, California

University of California Press, Ltd.

London, England

(C) 2003 by the Regents of the University of California

An earlier version of chapter 7 was published in Signs 26 (2): 4I 5-40. (C) 200 I by the University of Chicago. All rights reserved. I thank the University of Chicago Press for permission to reprint this article.

In chapter 2, the interviews with A. B. Santos and Juanita Santos and Edgar Gamboa previously appeared in Filipino American Lives by Yen Le Espiritu.

Reprinted by permission of Temple University Press.

(C) 1995 by Temple University. All Rights Reserved.

Table 3 was previously published as table 6.2 in "The Paradox of Assimilation: Children of Filipino Immigrants in San Diego," by Yen Le Espiritu and Diane L. Wolf. In Ethnicities: Children of Immigrants in America, edited by Ruben Rumbaut and Alejandro Portes. (C) $200 \mathrm{I}$ by the Regents of the University of California. Reprinted by permission of the University of California Press.

\section{Library of Congress Cataloging-in-Publication Data}

Espiritu, Yen Le, I963-.

Home bound : Filipino American lives across cultures, communities, and countries /

Yen Le Espiritu.

$$
\text { p. } \mathrm{cm} \text {. }
$$

Includes bibliographical references and index.

ISBN 0-520-22755-7 (cloth : alk. paper) ISBN o-520-23527-4 (paper : alk. paper)

I. Filipino Americans-Social conditions.

2. Filipino Americans-Ethnic identity. 3. FamilyUnited States. 4. United States-Relations-

Philippines. 5. Philippines-Relations-United States. 6. Transnationalism. 7. Racism-United States.

I. Title.

$\mathrm{EI}_{1} 8 \cdot \mathrm{F}_{4} \mathrm{E} 87 \quad 2003$

2002007139

Manufactured in the United States of America
$\begin{array}{llllllllll}\text { I2 II } & \text { IO } & 09 & 08 & 07 & 06 & 05 & 04 & 03\end{array}$

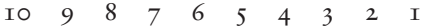

The paper used in this publication is both acid-free and totally chlorine-free (TCF). It meets the minimum requirements of ANSI/NISO Z39.48-I992 (R I997) (Permanence of Paper). 
For Abe, Evyn, Maya, and Gabriel ... the Filipino parts of me 
This page intentionally left blank 